\title{
PERBEDAAN HASIL BELAJAR ANTARA MODEL PEMBELAJARAN CLIS (CHILDREN'S LEARNING IN SCIENCE) DENGAN MENGGUNAKAN MEDIA KIT IPA DI SMP NEGERI 21 KOTA BENGKULU
}

\author{
Novi Ade Suryani ${ }^{1 *}$, Indra Sakti ${ }^{2}$, Andik Purwanto ${ }^{2}$ \\ ${ }^{1}$ Universitas Dehasen Bengkulu, Bengkulu \\ ${ }^{2}$ Pendidikan Fisika FKIP Universitas Bengkulu, Bengkulu \\ *Email: novi.adesuryani@gmail.com
}

\begin{abstract}
ABSTRAK
Penelitian ini bertujuan untuk: (1) Mengetahui hasil belajar dengan model pembelajaran CLIS (Children's Learning in Science) menggunakan Media Kit IPA di SMP Negeri 21 Kota Bengkulu. (2). Mengetahui hasil belajar dengan model pembelajaran CLIS (Children's Learning in Science) tanpa menggunakan Media Kit IPA di SMP Negeri 21 Kota Bengkulu. (3). Untuk mengetahui seberapa besar perbedaan hasil belajar fisika antara model pembelajaran CLIS (Children's Learning in Science) yang menggunakan media kit IPA dan tidak menggunakan Media Kit IPA di SMP Negeri 21 Kota Bengkulu. Metode penelitian ini adalah penelitian eksperimen dengan sampel terdiri dari dua kelas. Instrumen penelitian ini berupa 10 butir soal berbentuk pilihan ganda yang dibagi dalam tiga tahapan pembelajaran. Teknik analisis yang digunakan adalah analisis uji-t. Hasil dari penelitian ini bahwa hasil belajar yang dicapai oleh siswa dengan model pembelajaran CLIS (Children's Learning In Science) menggunakan media kit IPA diperoleh rata-rata sebesar 65,26, sedangkan hasil belajar yang dicapai siswa dengan model pembelajaran (Children's Learning In Science) tanpa menggunakan media kit IPA sebesar 61,67, dengan hasil perhitungan $\mathrm{t}_{\text {hitung }}$ sebesar 2,813 .
\end{abstract}

Kata kunci: Model Pembelajaran CLIS (Children's Learning in Science), Media Kit IPA, hasil belajar.

\section{PENDAHULUAN}

Peradaban manusia akan sangat diwarnai oleh tingkat penguasaan ilmu pengetahuan dan teknologi. Pengembangan ilmu pengetahuan dan teknologi akan bersumber pada Matematika dan Ilmu Pengetahuan Alam (IPA). Fisika sebagai salah satu unsur dalam IPA mempunyai peranan yang sangat penting dan strategis dalam pengembangan teknologi masa depan (Afrizon et al. 2012). Oleh karena itu dalam memacu ilmu pengetahuan dan teknologi proses pembelajaran fisika perlu mendapat perhatian yang lebih baik (Wirtha dan Rapi, 2008 ).

Konsep-konsep dasar dan prinsip-prinsip dasar di dalam fisika, atau umumnya ilmu pengetahuan alam, diungkapkan secara kuantitatif dalam bentuk abstraksi matematik. Hal ini yang membuat kebanyakan pengajaran fisika lebih menekankan pada pemberian rumusrumus fisika (Krips 1993). Fisika menjadi tampak sangat abstrak, jauh dari realitas. Siswa mengalami kesulitan dalam mengaitkan atau menginterpretasikan ungkapan matematika dari suatu hukum fisika dengan realitas fenomena alam. Akhirnya, matapelajaran fisika menjadi salah satu matapelajaran yang dipandang sulit untuk kebanyakan siswa.

Ada beberapa faktor yang diperkirakan menyebabkan hasil belajar fisika rendah. Pertama, padatnya meteri yang dituntut kurikulum sedangkan waktu yang ada tidak mencukupi, hal ini menyebabkan guru tergesagesa dalam memberikan pelajaran. Kedua, kurangnya keterlibatan siswa, komunikasi dan kerjasama dalam proses belajar mengajar. Ketiga, adanya kecendrungan siswa dalam belajar fisika hanya sekedar menghafal rumusrumus yang diberikan guru tanpa menguasai konsep fisika yang esensial dari pengalaman yang ditemuinya dalam kehidupan sehari-hari. Keempat, dalam mengerjakan tugas-tugas yang diberikan guru, siswa cenderung mencontoh pekerjaan temannya dari pada mengerjakannya sendiri.

Dewasa ini ada berbagai model pembelajaran yang telah dikembangkan dalam 
rangka meningkatkan keterlibatan siswa dalam menguasai pelajaran. Salah satu pembelajaran yang berkembang yang dapat digunakan yaitu dengan menggunakan model pembelajaran CLIS (Children's Learning in Science) yang dikembangkan oleh Driver (1985), Osborne \& Freyberg (1985), Scott, P. (1987).

Model CLIS tersebut dilandasi dengan pandangan konstruktivisme, berpusat pada siswa, melalui aktivitas hands-on/ mind-on, dan menggunakan lingkungan sebagai sumber belajar. Model pembelajaran CLIS dilaksanakan dalam lima tahap yaitu: orientasi, pemunculan gagasan, penyusunan ulang gagasan, dan mengkaji ulang perubahan gagasan (Sutarno,2006). Maka dengan diterapkannya model pembelajaran ini diharapkan siswa lebih dapat mengaplikasikan materi yang dipelajari ke dalam kehidupan sehari-hari.

Media merupakan salah satu kelengkanpan yang cukup penting yang diperlukan dalam proses pembelajaran. Penggunaan media pembelajaran yang tepat akan dapat meningkatkan pemahaman siswa dalam proses belajar mengajar. Oleh karena itu, dalam proses belajar mengajar guru berusaha menggunakan media yang tepat agar tujuan-tujuan yang diinginkan dapat tercapai dalam diri siswa.

Penelitian ini diharapkan dapat mengetahui hasil belajar dengan model pembelajaran CLIS (Children's Learning in Science) dengan menggunakan Media Kit IPA (Indrayani 2015, Juanda 2012, Sasmita 2017) dan tanpa menggunakan Media Kit IPA di SMP Negeri 21 Kota Bengkulu serta mengetahui perbedaan hasil belajar fisika yang telah diterapkan.

\section{METODE PENELITIAN}

Penelitian yang digunakan adalah penelitian eksperimen dan desain yang digunakan adalah quasi eksperimen (eksperimen semu). Adapun populasi penelitian ini adalah siswa kelas VIII semester II SMPN 21 Kota Bengkulu yang terdiri dari 4 kelas, mulai dari kelas VIII1 sampai VIII4. Setiap kelas terdiri dari 36-40 siswa. Pengambilan sampel dilakukan dengan teknik Purposive Sampling sehingga didapat 2 kelas yaitu kelas eksperimen $\mathrm{VIII}_{3}$ dan kelas kontrol $\mathrm{VIII}_{4}$ yang akan dijadikan kelas sampel.
Instrumen pengumpul data yang digunakan dalam penelitian ini adalah tes belajar kognitif yang dibuat berdasarkan kurikulum dan kisi-kisi soal.

Dalam penelitian ini analisis data yang digunakan ialah teknik analisis deskriptif untuk mengetahui mean dan simpangan baku, uji inferensial serta uji hiptesis dengan menganalisis data post-test secara signifikan dengan menggunakan program SPSS 17,0 for windows.

\section{Waktu dan Lokasi Penelitian}

Penelitian dilaksanakan pada bulan Februari 2014 di kelas VIII Semester genap SMP Negeri 21 Kota Bengkulu.

\section{HASIL DAN PEMBAHASAN}

Penelitian ini dilakukan dalam tiga kali pertemuan, yang terdiri dari tiga kali pertemuan membahas materi dan tiga kali post-test. Hasil tes yang didapat dari kedua kelas digunakan untuk menguji normalitas dan homogenitas kelas sampel dan dilanjutkan dengan pengujian hipotesis dengan uji-t untuk mengetahui perbedaan hasil belajar yang diperoleh dari model pembelajaran CLIS (Children's Learning in Science) dengan menggunakan media kit IPA dan tanpa media kit IPA.

Hasil nilai rata-rata untuk kedua kelas sampel dijadikan sebagai data untuk melakukan analisis statistik seperti menentukan mean, standar deviasi, dan uji hipotesis dengan uji-t.

Tabel 1. Hasil Belajar Siswa Kelas Eksperimen

\begin{tabular}{lllll}
\hline No & \multicolumn{1}{c}{ Ket. } & Pert. I & $\begin{array}{c}\text { Pert. } \\
\text { II }\end{array}$ & Pert. III \\
\hline 1. & $\begin{array}{l}\text { Nilai } \\
\text { Terendah }\end{array}$ & 40 & 30 & 40 \\
2. & $\begin{array}{l}\text { Nilai } \\
\text { Tertinggi }\end{array}$ & 90 & 90 & 90 \\
3. & $\begin{array}{l}\text { Nilai } \\
\text { Rata-rata }\end{array}$ & 65,53 & 65,79 & 64,47 \\
4 & $\begin{array}{l}\text { Standar } \\
\text { Deviasi }\end{array}$ & 10,58 & 14,07 & 11,32 \\
\hline
\end{tabular}




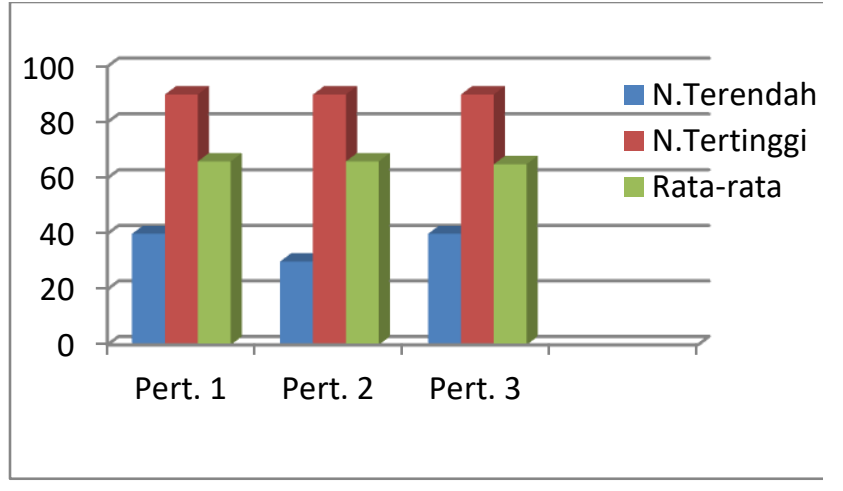

Gambar 1. Grafik persentase hasil belajar kelas eksperimen.

Tabel 2. Hasil Belajar Siswa Kelas Kontrol

\begin{tabular}{clccc}
\hline No. & \multicolumn{1}{c}{ Ket. } & Pert.I & $\begin{array}{c}\text { Pert. } \\
\text { II }\end{array}$ & Pert. III \\
\hline 1. & $\begin{array}{l}\text { Nilai } \\
\text { Terendah }\end{array}$ & 40 & 50 & 50 \\
2. & $\begin{array}{l}\text { Nilai } \\
\text { Tertinggi }\end{array}$ & 80 & 80 & 80 \\
3. & $\begin{array}{l}\text { Nilai } \\
\text { Rata-rata }\end{array}$ & 64,21 & 60,00 & 60,79 \\
4 & $\begin{array}{l}\text { Standar } \\
\text { Deviasi }\end{array}$ & 10,03 & 8,05 & 7,12 \\
\hline
\end{tabular}

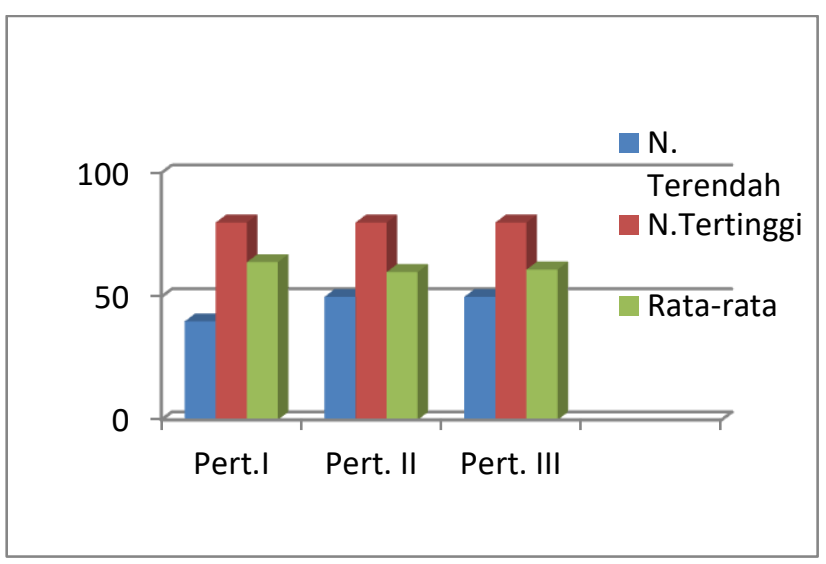

Gambar 2. Grafik persentase hasil belajar kelas kontrol.

Berdasarkan Tabel 1 dan 2 tersebut diketahui bahwa nilai rata-rata siswa yang diajar menggunakan model pembelajaran CLIS (Children's Learning in Science) dengan menggunakan media kit IPA lebih tinggi bila dibandingkan tanpa media kit IPA berdasarkan hasil posttest.

Dari hasil pengujian normalitas nilai signifikansi data diperoleh untuk kedua kelas $\hat{\alpha}$ $=0,083>0,05$. Untuk Uji homogen dilakukan dengan melihat probabilitas Levene Test atau Sig dengan taraf signifikansi 5\% (0,05). Dari perhitungan analisis data dengan menggunakan bantuan SPSS. 17,0 diperoleh nilai Sig untuk uji homogenitas sebesar 0,214 >0,05.

Pengujian hipotesis penelitian menggunakan uji-t, untuk mengetahui perbedaan hasil belajar. Berdasarkan hasil perhitungan uji-t menggunakan SPSS 17,0 maka diperoleh $\mathrm{t}_{\text {hitung }}=$ 2,813 dan $\mathrm{t}_{\text {tabel }}=1,71$

Tabel 3. Hasil perhitungan hipotesis menggunakan uji-t

\begin{tabular}{cccccc}
\hline \multicolumn{3}{c}{ t-test untuk persamaan dari rata-rata hasil post- } \\
\multicolumn{4}{c}{ test kedua sampel } \\
\hline $\mathrm{T}$ & $\begin{array}{c}\text { Deraja } \\
\mathbf{t}\end{array}$ & $\begin{array}{c}\text { Sig } \\
(\mathbf{2}-\end{array}$ & $\begin{array}{c}\text { Perbed } \\
\text { aan }\end{array}$ & $\begin{array}{c}\text { Perbedaan } \\
\text { interval taraf }\end{array}$ \\
& $\begin{array}{c}\text { kebeb } \\
\text { asan }\end{array}$ & $\begin{array}{c}\text { tail } \\
\text { ed) }\end{array}$ & $\begin{array}{c}\text { rata- } \\
\text { rata }\end{array}$ & \multicolumn{2}{c}{$\begin{array}{c}\text { kepercayaan } \\
\text { 95\% }\end{array}$} \\
& & & & $\begin{array}{c}\text { Teren } \\
\text { dah }\end{array}$ & $\begin{array}{c}\text { Terti } \\
\text { nggi }\end{array}$ \\
\hline 2,8 & 74 & 0,00 & 3,6 & 1,05 & 6,14 \\
13 & & 6 & & & \\
\end{tabular}

Dari data tersebut dapat diketahui bahwa $t_{\text {hitung }}>\mathrm{t}_{\text {tabel }}$, maka hipotesis $\mathrm{H}_{0}$ ditolak dan $\mathrm{H}_{1}$ diterima. Hal ini menunjukkan bahwa terdapat perbedaan yang signifikan antara hasil belajar siswa yang diajar dengan model pembelajaran CLIS (Children's Learning in Science) dengan menggunakan media kit IPA dan tanpa media kit IPA.

\section{KESIMPULAN}

Berdasarkan analisis data dalam penelitian ini diperoleh kesimpulan bahwa hasil belajar siswa yang menggunakan model pembelajaran CLIS (Children's Learning in Science) dengan menggunakan media kit IPA ternyata lebih tinggi daripada pembelajaran tanpa menggunakan media kit IPA. Hal ini juga dapat membuktikan bahwa media mempunyai pengaruh dalam proses pembelajaran. 


\section{REFERENSI}

Afrizon, R., Ratnawulan, R., \& Fauzi, A. (2012). Peningkatan Perilaku Berkarakter Dan Keterampilan Berpikir Kritis Siswa Kelas IX MTsn Model Padang pada Mata Pelajaran IPA-Fisika Menggunakan Model Problem Based Instruction. Jurnal Penelitian Pembelajaran Fisika, 1(1).

Driver Rosalind. 1985. Children's Ideas in Science. Philadelphia. Open University Press.

Indayani, L. (2015). Peningkatan prestasi belajar peserta didik melalui penggunaan media KIT IPA di SMP Negeri 10 Probolinggo. Jurnal Kebijakan dan pengembangan pendidikan, 3(1).

Juanda, T. (2012). Pembelajaran Fisika dengan CTL Melalui Media Pembelajaran Animasi dan KIT IPA Ditinjau dari Gaya Belajar dan Motivasi Berprestasi Siswa. Educatio, 7(2), 71-78.

Krips, M. F. (1993). MENGAPA MATA PELAJARAN FISIKA SELALU'PALING JELEK?. Jurnal Pengajaran MIPA, 1(1), 39-43.

Osborne, R., \& Freyberg, P. (1985). Learning in Science. The Implications of Children's Science. Heinemann Educational Books, Inc., 70 Court Street, Portsmouth, NH 03801.

Sasmita, P. R. (2017). Penerapan metode inkuiri terbimbing menggunakan media kit fisika: upaya meningkatkan aktivitas dan hasil belajar fisika siswa. Jurnal Ilmiah Pendidikan Fisika Al-Biruni, 6(1), 95-102.

Scott, P. (1987). A Constructivist View of Learning and Teaching in Science. Children's Learning in Science Project.

Sutarno,Nono. 2006. Materi dan Pembelajaran IPA SD. Universitas Terbuka

Wirtha, I. M., \& Rapi, N. K. (2008). Pengaruh model pembelajaran dan penalaran formal terhadap penguasaan konsep fisika dan sikap ilmiah siswa sma negeri 4 singaraja. Jurnal Penelitian dan Pengembangan Pendidikan, 1(2), 15-29. 